\title{
Development of Teaching Based on A Survey to Improve the Motivation and Learning Outcomes of Students in Thematic Learning in Class IV
}

\author{
Akmal Hadi Maulana*, Rochmiyati, Pargito, Suwarjo \\ Lampung University, Jl. Prof. Dr. Soemantri Brojonegoro No. 1 Bandar Lampung, Indonesia
}

\begin{abstract}
Development Of Inquiry-Based Materials To Increase Motivation And Learning Result Students On Tematic Learning In Class IV SD Negeri 4 Metro Timur. The purpose of this study is to produce an effective LKPD developed through inquiry model and test the difference of motivation and learning outcomes of students using with those who do not use LKPD based inquiry. The method used is research and development. The population of research is 65 students of class IV in SD Negeri 4 Metro Timur that is the fourth grade of B B is 32 students (as experiment class), and the grade IV A students are 33 people (as control class). Technique of collecting test data and questionnaire. Qualitative and quantitative data analysis techniques. Testing the first hypothesis and the second hypothesis using independent $t$ test technique. The result of this research are (1) Thematic LKPD based on a request for class IV SD N 4 Metro Timur which was developed based on the assessment of design experts and the material is declared vslit by experts. (2) The LKPD based on the thematic survey for class IV SD N 4 Metro Timur which has been developed is interesting to use as one of the media in the thematic learning process according to the students. (3) The thematic LKPD based on the thematic learning survey is used effectively in class IV SD N 4 Metro Timur. This is demonstrated by the improvement of student learning outcomes in thematic learning.
\end{abstract}

Keywords: student worksheets, inquiry, motivation to learn, student learning outcomes

DOI: $10.7176 / \mathrm{JEP} / 11-23-03$

Publication date:August $31^{\text {st }} 2020$

\section{Introduction}

The teacher is a facilitator for students in understanding all the materials taught to acquire optimal competence. One of the efforts teachers can make to help students better understand the material is to use the instructional material. The teaching material for the 2013 curriculum was provided in the form of textbooks, but although there are textbooks for students that have been provided, the teacher still creates and develops them so that students do not " do not tend to focus on a single source of learning as this is contrary to the objective of the curriculum to train creative and critical and multi-perspective graduates.

One of the teaching aids that can be used to provide materials is the student activity sheet (hereinafter abbreviated as LKPD). According to Trianto (2010: 73), the LKPD is educational material printed in the form of a task sheet that contains instructions, steps to complete the task. Prastowo (2014: 205-206) states that the LKPD has four functions, including as educational material which can minimize the role of educators, but rather activate students; as teaching material which makes it easier for students to understand the material provided; as a concise and rich educational material for the practice; and facilitate the implementation of student education.

Thanks to this LKPD, it is hoped that students can more easily understand the material, increase student learning activities, increase students' creativity and scientific thinking skills in accordance with the learning desired in the 2013 program. the learning which should be achieved through a learning process based on the 2013 curriculum is done through the scientific approach, which encourages students to observe better, ask questions, try / collect data, associate / reason and communicate.

On the basis of the results of direct interviews with teachers of the fourth year of the SD Negeri 4 Metro Timur (August 22, 2017) as well as observations from several classes of the SD Negeri 4 Metro Timur, the teachers still encounter many problems in the implementation work of learning. Problems that arise include poor student learning motivation, as students see the worksheet used so far in school as less attractive, difficult to understand, and the learning activities carried out by teachers using the spreadsheet are very boring. The LKPD used could not invite students to be active and creative, which focuses on summarizing the practical and monotonous questions of the practice.

The observation of learning activities in class IV SD Negeri 4 Metro Timur (August - September 2017), in general the teacher uses the conference method (teacher-centered). The teacher explains the material while the students listen only to the teacher's explanation. Not a few students playing alone or not paying attention to the teacher when the teacher explains the material. In addition, the use of LKPD in class IV SD Negeri 4 Metro Timur does not contain examples and images that can make students interested and enthusiastic about learning the material in the LKPD. This LKPD does not improve the ability to understand the concepts and problem solving skills of students, as students are not required to think scientifically. 
Based on the results of the analysis of the achievement of basic skills (KD) in thematic learning in class IV SD Negeri 4 Metro Timur during the odd semester of the academic year 2017/2018, it was found that the average learning outcomes of the students had not yet reached the minimum completeness criteria (KKM) of 70. Poor learning outcomes The student is indicated because his understanding of the concept of the subject is not optimal . The presentation of the LKPD used so far has been one of the causes of the students' poor learning outcomes. The LKPD used so far in class IV SD Negeri 4 Metro Timur does not help students better understand the subject. The LKPD used does not help students build their own understanding of the material. The steps presented in LKPD are not sufficient to train students to carry out scientific processes, to analyze and research concepts. LKPD is not yet commonly used to research or find a concept, and to apply concepts that already exist in life, it makes students inactive in learning activities.

Previous LKPDs did not develop students' scientific thinking skills in grade IV SD Negeri 4 Metro Timur, so an Explorative LKPD was needed that could be used to increase student motivation and mastery of concepts (understanding of material) as well as problem solving skills. With the use of Explorative LKPD, it is expected to be able to change the learning conditions from teacher centered to student centered so that learning motivation, mastery of concepts and students' problem solving skills increase. The results of the analysis of LKPD used in class IV SD Negeri 4 Metro Timur so far have not met the criteria of a scientific approach that is consistent with the 2013 curriculum.

Based on these initial findings, it is necessary to develop an existing LKPD with a learning model that can increase motivation and student learning outcomes in thematic learning, especially in class IV SD Negeri 4 Metro Timur.

According to Newstrom and Davis what is meant by learning motivation is the drive to overcome challenges, to progress, to develop, to get the best, towards perfection (Usman, 2006: 206). McClelland in Djaali (2007: 103) revealed that learning motivation is motivation that is related to the achievement of some intelligence or skill standards. According to Newstrom and Davis what is meant by learning motivation is the drive to overcome challenges, to progress, to develop, to get the best, towards perfection (Usman, 2006: 206). McClelland in Djaali (2007: 103) revealed that learning motivation is motivation related to the achievement of some intelligence or skill standards.

Based on some of the opinions above, it can be concluded that what is meant by learning motivation is the physiological and psychological conditions found in students that encourage them to carry out certain activities to achieve the highest possible learning outcomes.

According to Bahri, quoted by Umiarso (2010: 227), learning outcomes are the results obtained in the form of impressions that result in changes in the individual as a result of learning creativity. Sagala (2007: 12), also explained that the results to be obtained by students after participating in learning activities are to have the ability: 1) cognitive, namely the ability regarding knowledge, reasoning or thought, 2) affective that is the ability to prioritize feelings, emotions and reactions different reactions with reasoning, and 3) psychomotor is the ability that prioritizes physical skills.

Based on the opinions above it can be understood that the results to be obtained by a student after participating in learning activities in the form of behavioral changes that include cognitive, affective and psychomotor domains, so after the learning process there is a total change in attitudes and habits, and skills - skills in a positive direction.

The development of LKPD by using the inquiry learning model can be a solution for increasing student motivation and learning outcomes. As the results of Priyanto's research ((2016: 120) which found that the results of the development of media and learning models, namely interactive multimedia based on guided inquiry) is one alternative that can be used to develop social studies learning so as to increase student motivation and achievement.

Development of LKPD through inquiry learning according to Djamarah (2006: 22), is "learning to find and find for yourself." Sanjaya (2009: 194), explains the understanding of inquiry learning models is "a series of learning activities that emphasize the process of thinking critically and analytically to find and find answers themselves to a problem in question."

Based on the above understanding it can be understood that in the implementation of inquiry learning model, the teacher presents the lesson material not in the final form, but students are given the opportunity to search for it and find it for themselves by using the problem solving approach technique. According to Sanjaya (2009: 195) the main purpose of inquiry learning is to help students develop intellectual discipline and thinking skills by giving questions and getting answers on the basis of their curiosity.

The inquiry-based LKPD development is expected to improve students' motivation and learning outcomes in thematic learning, especially in class IV SD Negeri 4 Metro Timur. Through inquiry, the development of LKPD will be presented in accordance with scientific steps, namely formulating problems, determining hypotheses, processing data, drawing conclusions, and communicating, through learning activities to solve problems. So that through this research students' motivation and learning outcomes in thematic learning, especially in class IV SD Negeri 4 Metro Timur are increasingly optimal.

The purpose of this study is to produce inquiry-based LKPD in increasing motivation and student learning 
outcomes in thematic learning in class IV SD Negeri 4 Metro Timur and to test differences in motivation and learning outcomes of students who use those who do not use inquiry-based LKPD in class IV SD Negeri 4 Metro East.

\section{Research Methods}

This study uses research and development methods, namely research methods used to produce certain products and test the effectiveness of these products (Sugiyono, 2008: 407). The product developed is an inquiry-based LKPD. The research and development design used was quasi-experimental design (Quasi-ED) by comparing the motivation and learning outcomes of the experimental group (treated) with the control group (which was not treated). The development of LKPD follows the development of the Borg and Gall development model: 1) initial research and information gathering, 2) planning, 3) initial product format development, 4) initial trials, 5) product revisions, 6) field trials, 7) product revisions , 8) field trials, 9) final product revisions, 10) dissemination and implementation (Sugiyono, 2008: 298).

The population in this study were all grade IV students at SD Negeri 4 Metro Timur in the 2017/2018 school year with a total of 65 students. The sample in this study were all grade IV students at SD Negeri 4 Metro Timur which were divided into 2 (two) study groups in the 2017/2018 academic year with a total of 65 students.

Data collection techniques used in this study were test and questionnaire techniques. Written test technique, which provides written tests to students to determine the level of knowledge and mastery of students on thematic material as many as 20 multiple choice questions. Arrangement of measuring instruments based on indicators of each competency to be achieved. Questionnaire is given to students at the end of learning to find out student motivation. Prior to data collection, the research instrument tests were conducted including validity, reliability, difficulty level and distinguishing features.

The test results of the validity of the items to measure student learning outcomes of 20 questions, shows all are valid, because all items about the calculated $r$ value obtained is greater than the value of $r$ table $(0.444)$. Likewise the results of the questionnaire instrument validity testing to measure learning motivation, of the 20 questionnaire questions the results of the validity test showed that all were valid, because all items about the calculated $r$ value obtained were greater than the value of the $r$ table $(0.444)$.

The results of the reliability testing instrument in the learning motivation questionnaire, the calculated $r$ value of 0.939 is categorized high. The reliability test results of student learning outcomes items of 0.935 are categorized high. This means that all questions (20 questions) are reliable and can be used to measure motivation and learning outcomes of fourth grade students in this study.

The results of testing the level of difficulty items to measure student learning outcomes obtained results that as many as 13 items or $65 \%$ level of difficulty of the questions being. A total of 7 (seven) items or $35 \%$ difficulty level of easy questions. The results of the test of the differentiation of items on the student learning outcomes instrument, as many as 5 questions were categorized as low distinguishing power. A total of 4 about the distinguishing power is categorized as sufficient. As many as 7 about the distinguishing power is categorized as good. A total of 4 questions were categorized as being very good.

Testing the first and second hypotheses in this study used the two-difference test. Procedure for testing the effectiveness of inquiry-based LKPD in improving motivation and student learning outcomes in class IV SD Negeri 4 Metro Timur was performed data analysis using an independent t-test technique through motivation analysis and student learning outcomes using those not using LKPD-based inquiry.

\section{Results And Discussion}

\subsection{Research result}

Collection of preliminary information by analyzing the needs of students and teachers for the development of inquiry-based LKPD. In general, teachers at SD Negeri 4 Metro Timur consider the need to develop an LKPD that is suited to the needs and characteristics of students, so that it is effective in increasing motivation and student learning outcomes to be more optimal. Most of the fourth grade students at SD Negeri 4 Metro Timur stated that they needed the development of LKPD that was more interesting and made it easier for them to understand the material better and so that their motivation for learning increased. Thus it can be concluded that the inquiry-based LKPD development is needed for students in an effort to increase student motivation and learning outcomes.

Based on the results of the analysis of the needs of teachers and students in the development of LKPD, the planning carried out is the LKPD Development which is conducted based on inquiry. Material developed on Theme 8 "Area of My Place" Subtema 2 on "The Uniqueness of the Area of My Place". The development of the initial LKPD product format is in accordance with inquiry-based learning steps, namely orientation, formulating problems, proposing hypotheses, collecting data, testing hypotheses, and formulating conclusions.

The initial trial was submitted to material experts and design experts, namely material expert lecturers and design experts at Lampung University. Early researchers conducted a trial by validating 2 aspects, namely aspects of design and aspects of the material or content, by learning material experts. Content validation is carried out by 
competent experts on LKPD, thematic material and scientific approaches.

Based on the results of initial trials to material experts and design experts, several inquiry-based LKPD revisions were made as follows. The LKPD cover developed was suggested to write thematic-based LKPD through inquiry learning models so that the LKPD development model was more clear. In addition, including the name of the author gives clearer information about the author. Give contrasting colors to the contents of LKPD to make it more interesting for students and their enthusiasm to read it. Enter the source from the internet in the bibliography and address of the website. Hypothesis testing is done in class IV B as an experimental class and class IV A as a control class.

Table 1. Recapitulation of the Average Motivation Value of Class IVA and Class IVB Students

\begin{tabular}{|c|c|c|c|}
\hline \multirow{2}{*}{ No } & \multirow{2}{*}{ Rated aspect } & Class IV A & Class IV B \\
\cline { 3 - 4 } & & Experimentation Class & Control class \\
\hline 1. & $\mathrm{~A}$ & 56,6 & 58,3 \\
\hline 2. & $\mathrm{~B}$ & 53,3 & 55,5 \\
\hline 3. & $\mathrm{C}$ & 54,4 & 57,5 \\
\hline 4. & $\mathrm{D}$ & 55,5 & 53,8 \\
\hline 5. & $\mathrm{E}$ & 52,2 & $\mathbf{2 8 0 , 3}$ \\
\hline Summary & $\mathbf{2 7 2}$ & $\mathbf{5 6 , 0 6}$ \\
\hline Mean & $\mathbf{5 4 , 4 4}$ & $\mathbf{5 5 , 2 5}$ \\
\hline Enhancement & \multicolumn{2}{|c|}{ Enough } \\
\hline Category & \multicolumn{3}{|c|}{} \\
\hline
\end{tabular}

Based on the above assessment results, it can be concluded classically that the device developed by the researcher can be said to be effective because more than $75 \%$ respond to agree with an average number of 99.27 with a value of 77.31 with a good criterion value. The effectiveness of the use of LKPD can be seen from differences in learning outcomes of students before using LKPD and after using LKPD. Student learning outcomes in thematic inquiry-based learning can be seen as follows.

To find out the effectiveness of the inquiry-based LKPD, it can be tested with the average calculation of the nominal gain. The leveling that occurs before and after learning is calculated by the formula $\mathrm{g}$ factor (N-gain), which is:

$$
N-\text { gains }=\frac{(\text { postest })-(\text { pretest })}{\text { Skor maximum }- \text { pretest }}
$$

Table 2. Calculation of Cognitive Learning Outcomes of Inquiry-Based Pre-Test and Post-Test.

\begin{tabular}{|l|l|l|}
\hline Information & Pre-Test & Post-Test \\
\hline Values & 2270 & 2496 \\
\hline $\mathrm{N}$ & 32 & 32 \\
\hline Mean & 59,3 & 90,6 \\
\hline $\mathrm{N}-$ Gain & 0,10 & \\
\hline
\end{tabular}

$N-$ gains $=\frac{2496-2270}{100-2270}=0,10$

in the medium category, based on the results of the KKM analysis $(\geq 70)$ is $90.6 \%$, the inquiry-based LKPD is effectively used in class IV SD N 4 Metro Timur

\subsection{Research Discussion}

Suitability of the product produced with the Development Goals The purpose of this development research is to realize an inquiry-based LKPD. The development procedure used in the development refers to the learning media development model according to Praswoto (2011). LKPD developed to achieve mastery of competency standards: Apply the concepts and principles of thematic learning in solving problems. LKPD has been validated by experts. Some revisions have been made based on suggestions for improvement given by experts. Therefore, this LKPD is declared valid and can be used as a thematic learning media.

After the expert test is done, the next is a trial in learning activities. This trial is intended to see the suitability and effectiveness of the media in learning, because what is conceptualized by researchers and experts is not necessarily in accordance with reality on the ground. The first trial is a one-on-one test. In this test involving students in class IV SD Negeri 4 Metro East who were given time to study the LKPD. After the students finish using the LKPD, a questionnaire is given to find out the motivation of the students towards the LKPD. Based on the results of the questionnaire, students rated that learning media were good, with a percentage of $90.6 \%$. Overall, there is no need to revise the LKPD because there are no suggestions for improvement of the LKPD.

Strengths and Weaknesses of Product Development Activities The results of product development have several advantages. The advantages of this development product in the form of print-based media that can be used 
as a guide to learn for students independently by empowering the potential that exists in schools. Another advantage of the product development results in the form of LKPD compiled by applying incuri-based learning, is equipped with an evaluation to determine the level of mastery of the material and the achievement of basic competencies of each material. Weaknesses of the product development results are that the evaluation of learning programs using LKPD has not been implemented on a large scale.

Student motivation questionnaire sheet contains the statement of student motivation to be measured. Motivation towards learning is interest, enthusiasm, responsibility, working together, and solving problems with learning based on inquiry LKPD. Motivation of students is said to be appropriate because the total motivation value of 2285 with an average of 71.37. Thus it can be concluded that the inquiry-based LKPD appeals to students, includes interesting pictures, writing, and grammar, makes students enthusiastic in learning, easily understood by students, according to students 'characteristics and abilities, builds students' knowledge, and linking the material with the daily lives of students.

This is in line with the opinion of Van and Murray (2005: 166) "the inquiry approach supports the development of students effectively as students to better understand the relationship between the nature of inquiry and knowledge and know the characteristics of students". The development of inquiry-based LKPD products can increase the motivation of students in learning, can make students enthusiastic and actively participate in learning, students become more enthusiastic in learning because students are encouraged by the activities in LKPD, the pictures used in LKPD also makes students more active because the pictures used in LKPD are images that are in the student environment. The reading texts and the material used are also about the lives of students, so students can easily filter the material because it is in accordance with their experiences in daily life. This is in line with the opinion According to Thomas B. Roberts (in Lapono, 2008: 1.1) learning refers to the discourse of cognitive psychology, and seeks to analyze scientifically the mental processes and memory structures in learning activities.

So it can be concluded that, inquiry-based LKPD can make students become more enthusiastic and actively participate in learning, because the inquiry model conditions a conducive learning atmosphere that is responsive, the process of finding answers that are considered in accordance with the data or information obtained and can serve the needs of students .

Product development test results show that LKPD is effectively used as a thematic learning LKPD. This is obtained by comparing the learning outcomes of students after using the LKPD media with the KKM set for grade IV SD Negeri 4 Metro Timur, which is $\geq 70$, while the learning outcomes of students show an average value of students by 78 with the percentage of students passing by $90.6 \%$.

Based on the results of the test of learning outcomes after using the inquiry-based LKPD products, the LKPD results of the development were stated to be effectively used as learning media. That is because by using learning media, students can obtain material, find answers to problems, so they can remember from what they do and observe about thematic learning.

Based on the results of tests and revisions that have been made, the purpose of this development, according to the results of several studies in international journals namely Ufuk Töman, 2013. In the Journal on New Trends in Education and Their Implications and Nagihan Yildirim, Sevil Kurt, Alipaşa Ayas, in the journal of turkish science education concludes that LKPD is material where students are given steps / transactions about how they should learn, including activities that give learners the main responsibility in their own learning. LKPD is an integral part of a teaching material used as a teacher's chosen learning model, by collaborating LKPD with an active, effective and fun learning approach. So that LKPD is proven to be used as a very interesting media, very easy to use, very useful, and effective for thematic learning.

\section{Conclusion}

Based on the results of research and discussion, it can be concluded as follows (1) Thematic inquiry based LKPD for grade IV SD N 4 East Metro which has been developed based on the assessment of design experts and material declared vslit by experts. (2) thematic inquiry-based LKPD for class IV SD N 4 Metro Timur that has been developed is interesting to be used as one of the media in the thematic learning process according to students. (3) Thematic LKPD based on inquiry into thematic learning is effectively used in class IV SD N 4 Metro Timur. This is evidenced by improving student learning outcomes in thematic learning.

\section{References}

Adinda, N. Rizka. 2015. Development Of Laboratory Student Worksheet Based On Guided Inquiry In Thermochemistry Topic For XI Grade Senior High School. Unesa Journal of Chemical Education. Volume 04 Number 02, p. $434-439$.

Alrfooh, Atif Eid. 2014. Effectiveness of Applying Inquiry Strategy on the Achievement of Ninth Grade Students in Arabic Language Grammars in Petra: Jordan. Journal of Education and Practice. Volume 05 Number 09, p. $1-9$.

Annafi, Nurfidianty. 2016. The Effect of the Implementation of Guided Inquiry Based Student Worksheet in MAN 
1 Bima City. Journal of EST Chemistry Education Program, Bima School of Education. Volume 02 Number 02 , p. $98-104$.

Djaali. 2007. Educational Psychology. Earth Literacy. Jakarta.

Djamarah, Syaiful Bahri and Zain, Aswan. 2006. Teaching and Learning Strategies. Jakarta: Rineka Cipta.

Ersanto, Ganang Fajar. 2012. Implementation of Teams Games Tournament Cooperative Learning Combined with Guided Inquiry through Lesson Study to Increase Motivation and Learning Outcomes of Class X.10 Students of SMA Negeri 1 Batu. Essay. Not Published. Malang: State University of Malang.

Hosnul, Khotimah. 2017. The Influence of Guided Inquiry Learning Model with Mind Mapping Technique on Motivation and Learning Outcomes of Class VIII Students. On-Line Journal of State University of Malang. Volume 01 Number 01, p. $1-13$.

Jauhar, Mohammad. 2011. PAIKEM Implementation from Behavioristic to Constructivism. Jakarta: Prestasi Pustaka Publisher.

Prastowo, Andi. 2014. Creative Guide to Making Innovative Teaching Materials. Yogyakarta: Diva Press.

Priyanto, Wawan. 2016. Implementation of Guided Inquiry-Based Interactive Multimedia in Social Studies Learning for Class IV Elementary School Students. Primary School Mimbar Journal. Indonesian education university. Volume 3 Number 02, p. 120 - 135.

Rokhmah, Ainur. 2015. Development of Guided Inquiry-Based Student Worksheets (LKS) to Train Students' Skills in Conducting Experiments on Renewable Energy Sources Teaching Materials. Journal of Physics Education Innovation. Faculty of Mathematics and Natural Sciences, Surabaya State University. Volume 04 Number 02, p. $88-91$.

Sagala, Syaiful. 2007. Concept and Meaning of Learning. Bandung. Alfabeta.

Sanjaya, Vienna. 2009. Learning Strategy Oriented to Educational Process Standards. Jakarta: Golden.

Sugiyono. 2008. Quantitative, qualitative and $R \& D$ research models (8thed). Alfabeta. Bandung.

Trianto. 2010. Constructivist Oriented Innovative Learning Models. Jakarta: Catalog In Publication.

Umiarso and Gojali, Imam. 2010. School Quality Management in the Era of Educational Autonomy. Yogyakarta: IRCiSOD.

Usman, Husaini. 2006. Management Theory, Practice, and Educational Research. Jakarta: Earth Literacy. 